\title{
Prevalence and Forms of Bullying Perpetration and Victimization in Indian Adolescents
}

\author{
Mamta S Chhabria ${ }^{1}$, Aditi Rao ${ }^{2}$, Chandrika Rao ${ }^{3}$, Somashekar $\mathrm{AR}^{4}$
}

Mamta S Chhabria ${ }^{1}$, Aditi $\mathrm{Rao}^{2, *}$, Chandrika Rao ${ }^{3}$, Somashekar $\mathrm{AR}^{3}$

'Department of Internal Medicine, Rochester General Hospital, Rochester, NY, USA.

${ }^{2}$ Department of Internal Medicine, KLE Academy of Higher Education and Research (JNMC Campus), Belgaum, Karnataka, INDIA.

${ }^{3}$ Department of Paediatrics, MS Ramaiah Medical College, Bangalore, Karnataka, INDIA.

\section{Correspondence}

Dr. Aditi Rao

Department of Medicine, KLE Academy of Higher Education and Research, (JNMC Campus) Belagavi No 46, Surveyor Street, Basavanagudi, Bangalore 560004, INDIA.

Mobile no: +919686271047

Email: docaditi289@yahoo.com

History

- Submission Date: 27-07-2020

- Revised Date: 28-08-2020

- Accepted Date: 29-09-2020

DOI : 10.5530/ijmedph.2020.4.45

Article Available online

http://www.ijmedph.org/v10/i4

\section{Copyright}

(c) 2020 Phcog.Net. This is an openaccess article distributed under the terms of the Creative Commons Attribution 4.0 International license.

\begin{abstract}
Background: Bullying in childhood and adolescence has pervasive negative impacts in adulthood in both victims and bullies. There are few studies describing the prevalence of bullying in Indian schools, and few which have documented the various forms of bullying prevalent in our country. This study is being carried out with working hypothesis that various forms of bullying perpetration and victimisation exists in Indian urban schools. Objectives: To study the prevalence of bullying perpetration/ victimization, forms of bullying/victimization in Indian high school students. Methods: A cross sectional study conducted in 2 urban schools in Bangalore. A cohort of 435 adolescents (13-18yrs) were administered a pre validated 8 item questionnaire, part of the Student School Survey to assess bullying perpetration/ victimization. Results: 435 students in all, with 242 girls (55.6\%), 170 boys (39.1\%), 23 not revealing gender were studied. Total prevalence of bullying perpetration was $70.74 \%$, and victimization was $74.94 \%$. Verbal bullying was the most prevalent $(55.17 \%)$ with physical bullying $(40.46 \%)$ and cyber bullying $(15.86 \%)$ being less frequently reported. Similarly verbal victimization $(65.75 \%)$ was most prevalent followed by physical victimization $(40.23 \%)$ and cyber victimization $(14.48 \%)$. Conclusions: The information revealed by our study sensitizes doctors to the existing prevalence of bullying. Paediatricians and adolescent physicians should enquire about bullying from their adolescent patients and offer anticipatory guidance. Assessment of bullying can be implemented routinely in schools. A multi-targeted approach at individual/family level, school level, community level, State level and National level to make the school a safer environment for children can be adopted.
\end{abstract}

Key words: Urban high school children, Physical bullying, Verbal bullying, Cyber bullying, Cyber victimization.

\section{INTRODUCTION}

Various definitions of bullying exist in the absence of a universal definition. Bullying is defined as long-standing violence, physical or psychological, conducted by an individual or a group and directed against an individual, who is not able to defend himself in the actual situation, with a conscious desire to hurt, threaten or frighten that individual or put him under stress. ${ }^{1}$

Bullying is a subcategory of aggressive behaviour characterized by the following three minimum criteria: (1) hostile intent, (2) imbalance of power and (3) repetition over a period of time. ${ }^{2}$ If bullying is done by a group, it is called mobbing. ${ }^{3}$ Olweus describes bullying perpetration as "intentional, repeated, negative (unpleasant or hurtful) behaviour by one or more persons directed against a person (the victim) who has difficulty defending himself or herself." 4 Mob mentality, peer pressure, popularity, academic or athletic excellence, ethnic and racial characteristics of school cliques, physical appearance, financial differences between groups of students, dress sense are some factors which can lead to a power differential which propagates bullying. ${ }^{5}$

Cite this article : Chhabria MS, Rao A, Rao C, Somashekar AR. Prevalence and Forms of Bullying Perpetration and Victimization in Indian Adolescents. Int J Med Public Health. 2020;10(4):213-6. 
victimization in Indian high schools and to report the prevalence of various subtypes of bullying perpetration/victimization, the pattern of bullying perpetration/victimization across different age and gender groups this will aid physicians and pediatricians to give anticipatory guidance to adolescents and parents in their practice.

\section{MATERIALS AND METHODS}

The study was conducted in a cohort of children belonging to Standards $8^{\text {th }}, 9^{\text {th }}, 10^{\text {th }}, 11^{\text {th }}$ and $12^{\text {th }}(13-18$ years $)$ in 2 urban, co-educational high schools located in Bengaluru, Karnataka, India. Informed consent was obtained from the principals of the English medium schools and the students' parents and the purpose of the study was adequately explained. Children aged 12 years and older gave assent to participate in the study.

Each child was handed an individual copy of the questionnaire. The questionnaire was in English and researchers explained the scale clearly to groups of about 40 students before they answered. Confidentiality was maintained throughout the study. The Bullying Perpetration (Items 23-26) and Bullying Victimization (Items 35-38) sub-scales of the "School Student Survey" released by the CDC in the Compendium of Assessment Tools for Bullying Victimization, Perpetration and Bystander Experiences was used to carry out our study. This scale has been adapted from the original scale validated by Espelage and Holt. ${ }^{9,10}$ Of the four items each for Bullying Perpetration and Victimization respectively in the scale, 1 item adjudged Physical Bullying/Victimization, 2 items adjudged Verbal Bullying/Victimization and the last item determined Cyber Bullying/Victimization.

Students were asked to rate each item based on their experience on a scale of 0-4, as follows: 0 - Does not wish to reply, 1- Never, 2- 1 or 2 times, 3- several times, 4- A lot.

Bully Perpetration/ Victimization were defined as follows: 3,4- Severe Bully Perpetration/Victimization, 2- Moderate Bully Perpetration/ Victimization, 1- No Bully Perpetration/Victimization,0- Indeterminate. Based on the study carried out on "Prevalence of Bullying and Victimization among Sixth Graders with Reference to Gender, Socioeconomic Status and Type of Schools"11 and with a relative precision of 4 for bullying others, with a desired confidence level (1-alpha) of 95\%, the sample size was calculated as 428 students. The categorical variables of bullying perpetration/victimization were then expressed as \% with a 95\% confidence interval. Analysis of prevalence of bullying with other factors such as age, sex was also estimated. The association of factors with bullying was tested for statistical significance using Chi squared test.

\section{RESULTS}

The cohort consisted of 435 students in all, with 242 girls (55.6\%), 170 boys $(39.1 \%)$ and $23(5.2 \%)$ students choosing not to reveal their gender. Their ages ranged from 12 to 18 years of age, with 19 students not revealing their age [Figure 1].

\section{Bullying perpetration}

The overall bullying perpetration (including both moderate and severe bullying was estimated to be 70.74\%. Out of 170 Males, 126 (74.12\%) reported being perpetrators and $168(69.42 \%)$ of 242 Females admitted to being bullying perpetrators. As seen in Table 1, verbal bullying perpetration (55.17\%) was the commonest form of bullying perpetration in both males and females, followed by physical bullying perpetration $(40.46 \%)$ and cyber bullying perpetration being the least common (15.86\%).

In the stacked bar graph (Figure 2), we have depicted the numbers and percentages of the various subtypes of bullying and the severity of bullying perpetration (Moderate, Severe, No bullying in the total population, in males and females respectively.

It was found that male students(47.65\%) reported engaging in physical bullying more than female students(37.19\%) and this was statistically significant $(p=0.033)$.

Victimization: The total prevalence of victimization was found to be 74.94\%. Of them, 128 Male students (75.29\%) and 180 female students (74.38\%) admitted to being victims. Table 2 demonstrates that the prevalence of verbal victimization $(65.88 \%)$ was the commonest followed by physical victimization (40.23\%) and cyber victimization $(14.48 \%)$ in both males and females. The stacked bar graph (Figure 3) pictorially depicts a comparison of the different subtypes and grades of severity of victimization in Males, Females and the Total Population.

Verbal bullying including teasing/saying mean things was commonest followed by physical bullying such as pushing/shoving and cyber bullying in bullying perpetrators as well as victims

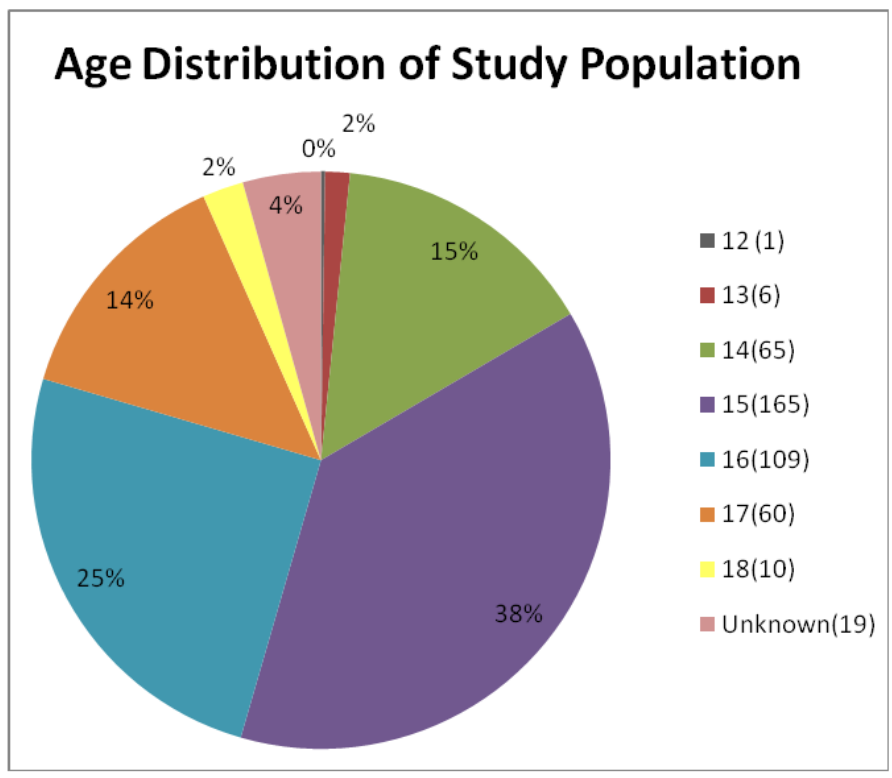

Figure 1: Age distribution of study population.

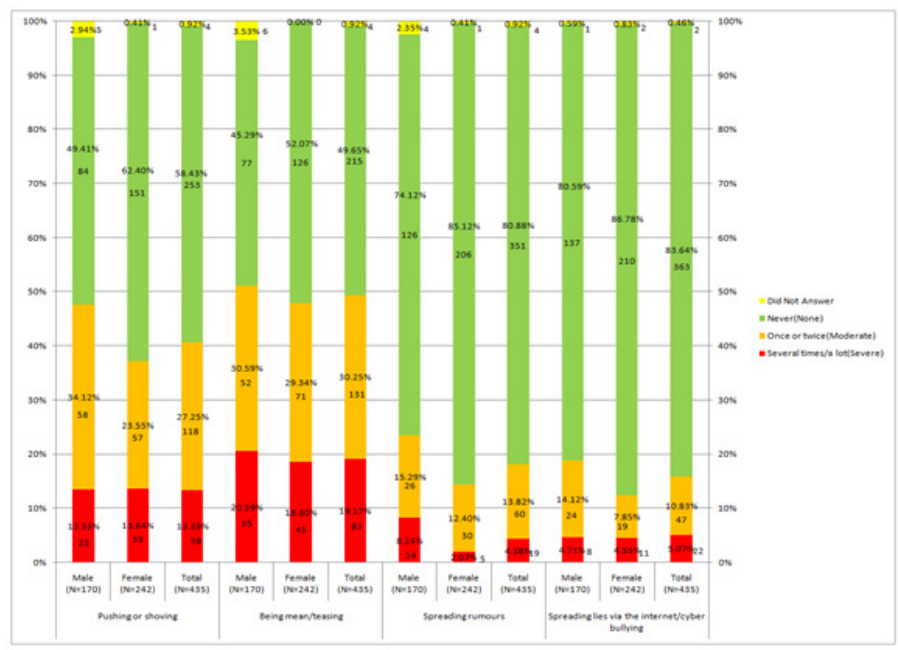

Figure 2: Subtypes and Severity of Bullying Perpetration in Males, Females and the Total Population. 
We also observed that Perpetration was less than Victimization in the total population. This could imply that students who exhibited bullying behaviour had more than one victim or that students either under reported their Bullying behaviour, or felt subjectively more victimized than they actually were.

There was no correlation with parental education or income levels. Relation with grades was also not significant in bullying perpetration and victimisation.

\section{DISCUSSION}

In this study, the total bullying perpetration was $70.57 \%$ and total victimization was 74.94\%. A study in Gujarat in 2017 revealed that overall prevalence of any form of bullying was $49 \%$, with bullies being $29.9 \%$ and victims being $29.7 \% .{ }^{12}$ Another study by Malhi et al. ${ }^{13}$ also carried out in an Indian sample concluded that the overall prevalence of bullying was $53 \%$, with $19.2 \%$ of the population being victims. A recent

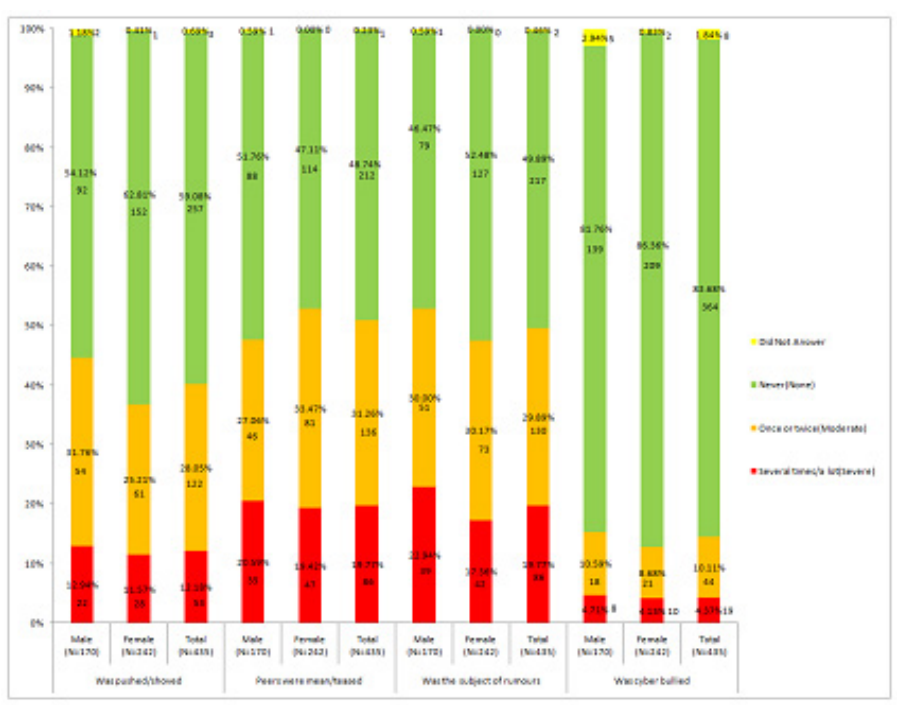

Figure 3: Subtypes and Severity of Victimization in Males, Females and the Total Population.

Table 1: Forms of Bullying Perpetration.

\begin{tabular}{|ccccc|} 
& $\begin{array}{c}\text { Total } \\
\text { Population } \\
(\mathrm{N}=435)\end{array}$ & $\begin{array}{c}\text { Male } \\
(\mathrm{N}=170)\end{array}$ & $\begin{array}{c}\text { Female } \\
(\mathrm{N}=242)\end{array}$ & $\begin{array}{c}P \text { value } \\
\text { (between } \mathrm{M} \\
\text { and F): }\end{array}$ \\
\hline All Forms & $307(70.57 \%)$ & $126(74.12 \%)$ & $168(69.42 \%)$ & 0.299 \\
Physical & $176(40.46 \%)$ & $81(47.65 \%)$ & $90(37.19 \%)$ & 0.033 \\
Verbal & $240(55.17 \%)$ & $98(57.65 \%)$ & $129(53.31 \%)$ & 0.383 \\
Cyber & $69(15.86 \%)$ & $32(18.82 \%)$ & $30(12.39 \%)$ & 0.072 \\
\hline
\end{tabular}

Table 2: Forms of Victimization.

\begin{tabular}{|ccccc|} 
& $\begin{array}{c}\text { Total } \\
\text { Population } \\
(\mathrm{N}=435)\end{array}$ & $\begin{array}{c}\text { Male } \\
(\mathrm{N}=170)\end{array}$ & $\begin{array}{c}\text { Female } \\
(\mathrm{N}=242)\end{array}$ & $\begin{array}{c}\text { P value } \\
\text { (difference } \\
\text { between M } \\
\text { and F): }\end{array}$ \\
\hline All Forms & $326(74.94 \%)$ & $128(75.29 \%)$ & $180(74.38 \%)$ & 0.833 \\
Physical & $175(40.23 \%)$ & $76(44.71 \%)$ & $89(36.78 \%)$ & 0.105 \\
Verbal & $286(65.75 \%)$ & $112(65.88 \%)$ & $159(65.70 \%)$ & 0.972 \\
Cyber & $63(14.48 \%)$ & $26(15.3 \%)$ & $31(12.81 \%)$ & 0.472 \\
\hline
\end{tabular}

article published by the Olweus Bullying Prevention Program reported the 2013 trends of Bullying in the US, where 15\% of students were victimized and $6 \%$ bullied others. ${ }^{14}$ We also found that males tended to be involved in physical bullying more than females $(p=0.033)$.

Our study found that verbal bullying was the most prevalent (55.17\%) with physical bullying $(40.46 \%)$ and cyber bullying (15.86\%) being less frequently reported. Similarly, verbal victimization $(65.75 \%)$ was most prevalent followed by physical victimization $(40.23 \%)$ and cyber victimization (14.48\%). This was comparable to the findings of studies by Kshirsagar et al. ${ }^{15}$ and Ramya et al. ${ }^{16}$

Cyber bullying is a problem of the new age of internet connectivity and social media and has not been studied as extensively as traditional forms of bullying. As per Mishna et al. $49.5 \%$ had been bullied online and $33.7 \%$ admitted to bullying others online. ${ }^{17}$ Another study by Hinduja and Patchin showed that $74 \%$ of the participants reported that bullying occurs online and almost $30 \%$ of the youth reported being victimized by others while online. ${ }^{18}$ Both the above studies describe the trends of cyber bullying in the US. Our findings have demonstrated that cyber bullying perpetration/victimization isn't as widespread in our sample.

Bullying behaviour is a complex issue. Previous research on bullying has suggested that the aetiology of bullying is more directly related to conditions at home rather than conditions at school. Environmental factors like watching violence in media, ${ }^{19}$ dysfunctional families ${ }^{20}$ and presence of peer groups contribute to bullying. The perpetrator often has a better self-esteem but low empathy compared to the victim. ${ }^{21}$ The development of an instinct to dominate or an instinct to be subdued and also gender power differences in society all play a role in the aetiology of bullying behaviour.

There have been studies to identify the role of genetics and understand the intricate interplay between genetics and environmental influences in bullying perpetration and victimization. There is compelling evidence from twin studies that heritable influences are a contributor to the development of antisocial behaviour. ${ }^{22,23}$ Bullying maybe an evolutionary adaptation of individuals with inheritable traits that enable bullying. ${ }^{24,25}$ Inheritable traits include negative emotionality, ${ }^{26}$ poor impulse control, ${ }^{27}$ sensation seeking behaviour and poor emotional regulation. ${ }^{28}$ Swearer and Hymel ${ }^{29}$ state that bullying stems from complex interactions between individuals and the contexts in which they function, both proximal (i.e., family, peers, school climate) and distal (i.e., societal, cultural influences) and all these influences need to be addressed by a multi-target approach. Bullying victimisation leaves adverse impact even in adulthood. Bullying is a form of chronic allostatic stress, which, if not given adequate time to recover from can lead to hormonal, inflammatory and metabolic responses- increasing the child's risk for chronic diseases such as heart disease and diabetes in adulthood. ${ }^{7}$ An increased DNA methylation of SERT (serotonin transporter gene) in the victimized twin and also a blunted cortisol response ${ }^{30}$ has been observed in identical twins. These changes are linked to poor coping strategies and increased risk of many psychiatric and mood disorders.

At present, no separate legislation exists in India to deal with bullying at school level. In 2015, the CBSE board issued a notice to all schools to set up anti-bullying committees and take strict action in all cases of bullying. ${ }^{31}$ The UGS (University Grants Commission) in 2009 passed regulations to help prevent bullying which include measures such as toll free helplines, textbooks to include chapters on ragging, periodic psychological counselling of all students, exemplary punishment of the perpetrators in accordance with the Criminal Procedural Code and an affidavit signed by parents and students at the time of admission. ${ }^{32}$

The limitations of our study were that we used self-reported questionnaires and did not have an equal representation of boys and 
girls. Furthermore, our study was carried out in co-educational schools and the findings are probably different in the unique environments fostered in all boys and all girls schools. These differences are definitely worth exploring in further studies.

In conclusion, the information revealed by our study sensitizes doctors to the existing prevalence of bullying. Paediatricians and adolescent physicians should enquire about bullying from their adolescent patients and offer anticipatory guidance. Assessment of bullying can be implemented routinely in schools. A multi-targeted approach at individual/family level, school level, community level, State level and National level to make the school a safer environment for children can be adopted.

\section{CONFLICT OF INTEREST}

The authors declare no Conflict of interest.

\section{ABBREVIATIONS}

CDC: Centres for Didease Control and Prevention.

\section{REFERENCES}

1. Heald TR. Judgement in the Case between R.H Walker and Derbyshire County Council. Nottingham: County Court Records. 1994.

2. Burger C, Strohmeier D, Spröber N, Bauman S, Rigby K. How teachers respond to school bullying: An examination of self-reported intervention strategy use, moderator effects and concurrent use of multiple strategies. Teaching and Teacher Education. 2015;51:191-202.

3. Arora CMJ. Defining bullying: Toward a clearer general understanding and more effective intervention strategies. School Psychology International. 1996;17(4):317-29.

4. Olweus D. Bullying at School: Basic Facts and Effects of a School Based Intervention Program. J Child Psychol Psychiatry. 1994;35(2):1171-90.

5. Vaillancourt T, Hymel S, McDougall P. Bullying is Power. Journal of Applied School Psychology. 2003;19(2):157-76.

6. Hawker D, Boulton M. Twenty Years' Research on Peer Victimization and Psychosocial Maladjustment: A Meta-analytic Review of Cross-sectional Studies. J Child Psychol Psychiatry. 2000;41(4):441-55.

7. Zarate-Garza PP, Biggs BK, Croarkin P, Morath B, Leffler J, Cuellar-Barboza $A$, et al. How Well Do We Understand the Long-Term Health Implications of Childhood Bullying?. Harv Rev Psychiatry. 2017;25(2):89-95.

8. Haynie D, Nansel T, Eitel P, Crump A, Saylor K, Yu K, et al. Bullies, Victims and Bully/Nictims: Distinct Groups of At-Risk Youth. J Early Adolesc. 2001;21(1):2949.

9. Espelage DL, Holt M. Bullying and victimization during early adolescence: Peer influences and psychosocial correlates. J Emotional Abuse. 2001;2(2-3):123-42.

10. Espelage DL, Holt M, Henkel RR. Examination of peer group contextual effects on aggression during early adolescence. Child Dev. 2003;74(1):205-20.

11. Shujja S, Atta M, Shujjat JM. Prevalence of Bullying and Victimization among Sixth Graders with Reference to Gender, Socio-economic Status and Type of Schools. J Soc Sci. 2014;38(2):159-65.
12. Patel HA, Varma J, Shah S, Phatak A, Nimbalkar SA. Profile of Victims among Urban and School Going Adolescents in Gujarat. Indian Pediatr. 2017;54:841-4.

13. Malhi P, Bharti B, Sidhu M. Aggression in Schools: Psychosocial Outcomes of Bullying Among Indian Adolescents. Indian J Pediatr. 2014;81(11):1171-6.

14. Limber S, Olweus D, Luxenberg H. Bullying in U.S. schools. 2013. Re - trieved from http://www.violence preventionworks.org/public/index.page accessed on Aug 2018

15. Kshirsagar VY, Agarwal R, Bavdekar SB. Bullying in Schools: Prevalence and Short-term Impact. Indian Pediatr. 2007;44(1):25-8.

16. Ramya SG, Kulkarni ML. Bullying among school children: Prevalence and association with common symptoms in childhood. Indian $\mathrm{J}$ Pediatr. 2011;78(3):307-10

17. Mishna F, Cook C, Gadalla T, Daciuk J, Solomon S. Cyber Bullying Behaviors among Middle and High School Students. Am J Orthopsychiatry. 2010;80(3):362 74.

18. Patchin JW, Hinduja S. Bullies Move Beyond the Schoolyard. Youth Violence Juv Justice. 2006;4(2):148-69. doi: 10.1177/1541204006286288.

19. Rowell HL. The Impact of Electronic Media Violence: Scientific Theory and Research. J Adolesc Health. 2007;41(6 Suppl):S6-13.

20. Patterson GR, Dishion TJK. Adolescent growth in new forms of problem behaviours: Macro and micro-peer dynamics. Prevention Science. 2000;1(1):313.

21. Olweus D, Limber SP. Bullying in school: evaluation and dissemination of the Olweus bullying prevention program. Am J Orthopsychiatry. 2010;80(1):124-34

22. Moffitt TE. The new look of behavioral genetics in developmental psychopathology: gene-environment interplay in antisocial behaviors. Psychological Bulletin. 2005;131(4):533-54.

23. Rhee SH, Waldman ID. Genetic and Environmental Influences on Antisocial Behavior: A Meta-Analysis of Twin and Adoption Studies. Psychological Bulletin. 2002;128(3):490-529.

24. Volk AA, Joseph AC, Andrew VD, Zopito AM. Is adolescent bullying an evolutionary adaptation?. Aggressive Behavior. 2012;38(3):222-38.

25. Jun-Bin K, Wong JS. Survival of the Fittest and the Sexiest: Evolutionary Origins of Adolescent Bullying. Journal of Interpersonal Violence. 2015;32(17):2668-90.

26. Pellegrini AD, Bartini M. A longitudinal study of bullying, victimization and peer acceptance during the transition from primary school to middle school. Am Educ Res J. 2000;37(3):699-725.

27. Marini ZA, Dane AV, Bosacki SL, YLC-CURA. Direct and indirect bully-victims: Differential psychosocial risk factors associated with adolescents involved in bullying and victimization. Aggr Behav. 2006;32(6):551-69.

28. Ball H, Arseneault L, Taylor A, Maughan B, Caspi A, Moffitt TE. Genetic and environmental influences on victims, bullies and bully-victims in childhood. Journal of Child Psychology and Psychiatry. 2008;49(1):104-12.

29. Swearer SM, Hymel S. Understanding the psychology of bullying: Moving toward a social-ecological diathesis-stress model. American Psychologist. 2015;70(4):344-53.

30. Ouellet-Morin I, Wong CC, Danese A, Pariante CM, Papadopoulos AS, Mill $\mathrm{J}$, et al. Increased serotonin transporter gene (SERT) DNA methylation is associated with bullying victimization and blunted cortisol response to stress in childhood: A longitudinal study of discordant monozygotic twins. Psychol Med. 2013;43(9):1813-23.

31. Parashar S. CBSE guidelines for Prevention of Bullying and Ragging in Schools. $9^{\text {th }}$ March, 2015. (D.O No. 12-19/2012-RMSA-I). Circular No. Acad.-17/2015.

32. New Delhi (India). University Grants Commission. No. F.1-16/2009(CPP-II) UG. Regulations on curbing the menace of Ragging in higher educational institutions. 2009. $4^{\text {th }}$. 2009. 